\title{
Orebody Characteristics and Deposit Genesis Analysis of the Ore Cluster I of Qunli Iron Mine in Golmud, Qinghai Province, China
}

\author{
Yuan Kequan, Liu Yongqiang, Ji Shangwen \\ Qinghai Second Institute of Nonferrous Geological Exploration, 810000, China
}

Keywords: Qunli of golmud city, Iron mine, Ore cluster i, Geological characteristics, Genesis of the deposit

\begin{abstract}
Qunli Iron Mine is in the mixed petrified gneiss interbedded with marble and skarn strata of the Lower Rock Formation of the Jinshuikou Group formed in the Lower Proterozoic, and it belongs to a skarn deposit related to migmatization. The regional tectonic structure is located in the central and western sections of the Qimantag-Dulan orogenic belt. The metallogenic belt belongs to the Qimantag-Dulan Hualixi iron, cobalt, bismuth, lead, zinc, copper and silver metallogenic belt. The area has experienced many complicated and strong tectonic movements, and the structural traces of different scales and mechanical properties are well developed. In particular, the northwest-westward compressive and torsional faults constitute the main structural framework in the region, which plays an important role in controlling the distribution of strata, magmatic rocks, metamorphism and mineral resources in various periods.
\end{abstract}

\section{Introduction}

The related exploration has basically found out the stratum, structure, magmatic rock distribution, shape, occurrence and the relationship with mineralization in the general exploration area of Ore Cluster I (exploration lines 10-21 of Ore Cluster I). The spatial location, scale, form, occurrence, ore quality and changes of the ore bodies in this area above the $4100 \mathrm{~m}$ elevation in this area have been basically ascertained. The related survey also roughly showed the distribution, scale and occurrence of the stratum, structure and magmatic rock in the periphery of the general exploration area. The ore-bearing horizon, scale and spatial distribution in this area were roughly ascertained, and 24 concealed magnetic bodies were delineated in the area, including 5 magnetite bodies, 4 speculated magnetite bodies and 15 unidentified magnetic bodies. All these have laid a solid foundation for the further development of geological survey.

\section{Regional Geological Background}

\subsection{Stratum}

The exposed strata in the area include the lower rock group $\left(\mathrm{Pt}_{1} \mathrm{jn}^{\mathrm{a}}\right)$ and upper rock group $\left(\mathrm{Pt}_{1} \mathrm{jn}^{\mathrm{b}}\right)$ of the Lower Proterozoic Jinshuikou Group, Upper Ordovician Ironstone Das Carbonate Formation $\left(\mathrm{O}_{3} \mathrm{ts}^{\mathrm{c}}\right)$, Upper Devonian Qigaisu Group of conglomerate $\left(\mathrm{D}_{3} q \mathrm{~g}^{\mathrm{a}}\right)$ and volcanic rock $\left(\mathrm{D}_{3} q g^{\mathrm{b}}\right)$, Upper Carboniferous Diaosu Formation $\left(\mathrm{C}_{2} \mathrm{~d}\right)$ and Permian $\left(\mathrm{P}_{1}\right)$, Upper Triassic $\left(\mathrm{T}_{3}\right)$, Neogene $(\mathrm{N})$ and Quaternary (Q).

\subsection{Structure}

Tectonic overview of the area: Northwest-west ward structural traces constitute the main structure in the area. It includes folds, schisms, and compressive faults with a structural surface of northwest-west ward, and mainly consists of faulted structures. Associated with these compressive structural planes are north-north-east tensile faults, north-east-east tensile torsional faults, and north-north-west compressive torsional faults.

\subsection{Magmatic Rocks}

The intrusive activity is strong in this area, and the intrusive rock masses are developed. They 
belong to three magmatic cycles of the Variscan, Indosinian and Yanshanian.

\subsection{Metamorphic Rocks}

In this area, there are three forms of metamorphism (regional metamorphism, contact metamorphism and dynamic metamorphism), which form complex metamorphic rocks.

\section{Regional Geophysical Characteristics}

\subsection{Aeromagnetic Anomaly}

Among the aeromagnetic anomalies distributed in the area, there are two positive anomalies (028 and 029), and the local positive anomalies on the background of negative magnetic fields are 004, 005, 008, 009, and 010 (as shown in Figure 1). It is speculated that Qunli Iron Mine may be related to the 004 anomaly. These anomalies are distributed in a belt-like northwest-west direction, basically consistent with the direction of the tectonic line. They all have the characteristics of low strength (usually in the tens of nT, up to about 110nT), large scale and obvious concentrated centers. According to the analysis of the geological locations where anomalies occur, the centers of anomaly concentrations are mostly located in favorable mineralization locations such as structures, rock mass development areas and stratigraphic transition locations.

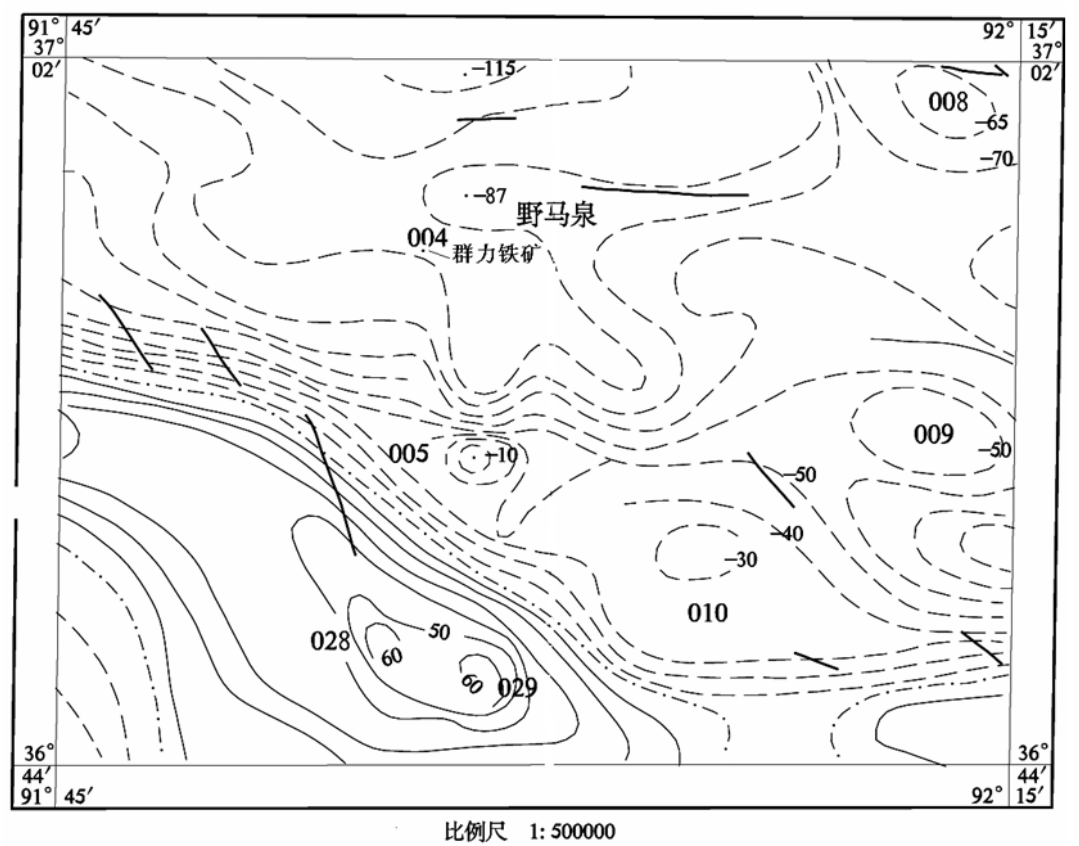

Fig.1 Plan of Aeromagnetic Anomalies in Yemaquan-Qunli Area, Golmud, Qinghai Province

\subsection{Geomagnetic Anomaly}

The geomagnetic anomalies are mainly distributed in two areas bounded by the middle reaches of the Bayinguole River. Based on this, it is divided into two local anomaly zones in the north and the south. The anomaly on the north side is mainly distributed in the metamorphic rock area, and that on the south side is mainly distributed on the edge and contact zone of the rock mass. The south zone has not been checked for abnormalities. In the subsequent prospecting work, the Qunli Iron Mine was discovered, which fits well with the delineated CVIII-3 geomagnetic anomaly (as shown in Figure 2). This indicates that the geomagnetic anomaly in this region has a close genetic relationship with iron polymetallic deposits, which is favorable for finding iron polymetallic deposits. 


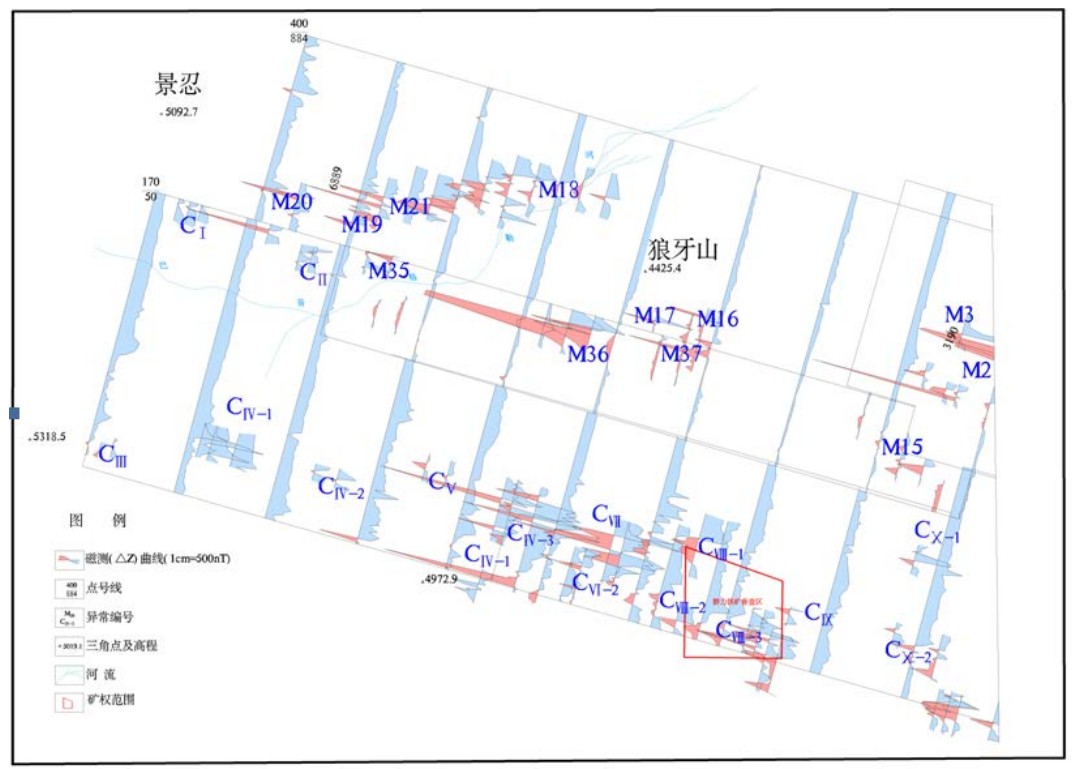

Fig.2 Plan View of Ground Magnetic Survey Section in Qunli Area

\subsection{Regional Geochemical Characteristics}

This area has experienced complicated geological processes in the long process of geological evolution. The complex and intense structural changes, magma intrusion, regional dynamic metamorphism, and hydrothermal action along the fault zone in multiple phases have created the geochemical field in the area, which has resulted in the enrichment or depletion of some elements.

The geochemical anomalies, geochemical high-content points and heavy concentrate anomalies in this area overlap and appear in a concentrated manner, and their distribution is obviously controlled by the distribution of the North-West-West-trending faults in this area and the multi-phase magmatic rock bodies exposed in this area. It can be seen that the mineralization geological background conditions in the area are extremely favorable. It is promising to find polymetallic minerals based on $\mathrm{Fe}, \mathrm{Cu}, \mathrm{Pb}, \mathrm{Zn}, \mathrm{Ag}, \mathrm{Sb}, \mathrm{Sn}, \mathrm{W}$ and other elements in this area.

\section{Regional Minerals}

Table 1 List of Characteristics of Ore (Deposit) Points

\begin{tabular}{|c|c|c|c|c|c|}
\hline Mineral & Origin & \multicolumn{2}{|l|}{ Coordinate } & Geological profile & Genetic \\
\hline $\begin{array}{l}\text { Kendekeke Iron } \\
\text { Polymetallic } \\
\text { Ore } \\
\text { (11) }\end{array}$ & $\begin{array}{l}\text { On the east bank } \\
\text { of the Bayinguole } \\
\text { River; in the } \\
\text { Kendekeke ditch } \\
\text { on the southern } \\
\text { slope } \\
\text { Langyashan. }\end{array}$ & $91^{\circ} 50^{\prime} 16^{\prime \prime}$ & $37^{\circ} 01^{\prime} 00^{\prime \prime}$ & $\begin{array}{l}\text { Lithology: clastic rock interbedded with volcanic rock group } \\
\text { of Upper Ordovician Tieshidasi Formation }\left(\mathrm{O}_{3} \mathrm{ts}^{\mathrm{a}}\right) \text {; rhyolite, } \\
\text { rhyolite tuff and dacite tuff lava of the } \mathrm{Upper}^{\mathrm{a} \text { Devonian }} \\
\text { Qigaisu Group Volcanic Formation }\left(\mathrm{D}_{3} \mathrm{qg}^{\mathrm{b}}\right) \text {; variegated } \\
\text { glutenite, siltstone, dolomitic marble and crystalline limestone } \\
\text { of Dagangou Formation of Lower Carboniferous; dacian tuff } \\
\text { lava, andesite and volcanic breccia of Upper Triassic system } \\
\left(\mathrm{T}_{3}\right) \text {. The ore bodies occur at the bottom of the Carboniferous } \\
\text { and the top of the Upper Ordovician Tieshidasi Group. }\end{array}$ & Skarn type \\
\hline $\begin{array}{l}\text { Qunli Iron } \\
\text { Mine } \\
\text { (15) }\end{array}$ & Qunli area & $91^{\circ} 50^{\prime} 26^{\prime \prime}$ & $36^{\circ} 54^{\prime} 36^{\prime \prime}$ & $\begin{array}{l}\text { The stratum is the Proterozoic Jinshuikou Group }\left(\mathrm{Pt}_{1} \mathrm{n}^{\mathrm{a}}\right) \\
\text { mixed petrified gneiss interbedded with marble and skarn. } \\
\text { The ore body occurs in the skarn related to the migmatization. }\end{array}$ & \\
\hline $\begin{array}{l}\text { Hongshan Iron } \\
\text { Mine } \\
\text { (12) }\end{array}$ & $\begin{array}{l}\text { About } 2 \mathrm{~km} \text { south } \\
\text { of Langyashan }\end{array}$ & $91^{\circ} 48^{\prime} 50^{\prime \prime}$ & $37^{\circ} 01^{\prime} 25^{\prime \prime}$ & $\begin{array}{l}\text { The stratum is Upper Carboniferous Sijiaoyanggou Formation } \\
\text { (C3s) marble. The ore body occurs in the skarn in the outer } \\
\text { contact zone of the potash feldspar granite. }\end{array}$ & \\
\hline $\begin{array}{l}\text { Yeniugou } \\
\text { Copper Mine } \\
\text { (16) }\end{array}$ & $\begin{array}{l}\text { The west side of } \\
\text { Yeniugou. }\end{array}$ & $91^{\circ} 49^{\prime} 05^{\prime \prime}$ & $36^{\circ} 50^{\prime} 15^{\prime \prime}$ & $\begin{array}{l}\text { The lithology is reddish-off-white monzonitic granite. }\left(\eta \gamma_{4}{ }^{c}\right) \\
\text { and medium-fine-grained granite, and the two are in phase } \\
\text { transition relationship. The ore bodies are produced at the } \\
\text { boundary of the lithofacies and are lenticular and saccate. }\end{array}$ & $\begin{array}{l}\text { Hydrothermal } \\
\text { Type }\end{array}$ \\
\hline
\end{tabular}

The area is rich in minerals and there are many kinds of minerals. There are five known deposits and mineralization points (as shown in Table 1). Most of the iron-based polymetallic minerals in this area are skarn type, followed by hydrothermal filling type.

The distribution of iron, non-ferrous metals (copper, lead, zinc, cobalt, bismuth, molybdenum, etc.) and precious metals (gold, silver) are obviously controlled by strata, structures, and magmatic 
rocks. Fe, Au, Co and Bi minerals occur in the Tanjianshan Group (OST) and the Lower Proterozoic Jinshuikou Group. Copper, lead, zinc and other minerals mainly occur in the Carboniferous strata, and the mineralization is related to magmatic intrusion. The minerals in this area are mostly produced in the skarn in the outer contact zone of the intermediate-acid intrusive rocks formed in the Indosinian and Yanshanian periods. Most of the minerals formed are skarn type and are multi-phased.

\section{Geological Characteristics of the Deposit}

The deposit is a medium-scale Fe-Cu deposit dominated by iron. Cu ore bodies are only found in a small amount in the Ore Cluster $\mathrm{V}$ in the east of the mining area. According to the different distribution positions of ore (mineralized) bodies, they are roughly divided into five ore body groups (Ore Clusters I, III, IV, V and VI), and the Ore Group I which is distributed in the central and western part of the mining area is the largest one. In each ore body group, several ore bodies are delineated according to the distribution position of the ore bodies and industrial indicators. A total of 42 iron ore bodies and 5 copper ore bodies are delineated.

\subsection{Main Ore Body Characteristics}

The Ore Body I -1 is a blind one, distributed between lines 21-3, with an ore body distribution elevation of $4180 \mathrm{~m} \sim 4485 \mathrm{~m}$. The ore body has a length of $922 \mathrm{~m}$, an inclined depth of $110-176 \mathrm{~m}$, and a maximum depth of $375 \mathrm{~m}$. The general thickness of a single engineering ore body is $1.20-2.30 \mathrm{~m}$ and the maximum thickness is $5.44 \mathrm{~m}$. The ore body is vein-like and lens-like, and its appearance is $340^{\circ} \sim 10^{\circ} \angle 40^{\circ} \sim 44^{\circ}$. The ore is mainly magnetite, followed by pyrite magnetite ore; the average grade is $\mathrm{TFe} 36.46 \%$, and $\mathrm{mFe} 32.38 \%$.

The Ore Body I -3 is a blind ore body. It is the largest one in the mining area and is distributed between lines $21-8$, with a distribution elevation of $4080 \mathrm{~m} \sim 4495 \mathrm{~m}$. The ore body has a length of $1561 \mathrm{~m}$, an inclined depth of $231-296 \mathrm{~m}$, and a maximum depth of $388 \mathrm{~m}$. The general thickness of a single engineering ore body is $0.86-8.66 \mathrm{~m}$, and the maximum thickness is $9.96 \mathrm{~m}$. The ore body is lens-like and vein-like, and its appearance is $340^{\circ} \sim 20^{\circ} \angle 18^{\circ} \sim 50^{\circ}$. The ore is mainly magnetite, followed by pyrite magnetite ore, and the average grade is TFe $40.08 \%$ and $\mathrm{mFe} 36.40 \%$.

The Ore Body I -4 is a blind ore body, distributed between the Line 21-2, with a distribution elevation of $4100 \mathrm{~m} \sim 4450 \mathrm{~m}$. The ore body has a length of $1577 \mathrm{~m}$, an inclined depth of $101-295 \mathrm{~m}$, and a maximum depth of $376 \mathrm{~m}$. The general thickness of a single engineering ore body is $0.65-12.10 \mathrm{~m}$, and the maximum thickness is $23.20 \mathrm{~m}$. The ore body is lens-like and vein-like, and its appearance is $350^{\circ} \sim 10^{\circ} \angle 29^{\circ} \sim 54^{\circ}$. The ore is mainly magnetite, followed by pyrite, magnetite and specularite, of which specularite is mainly distributed between the 9-2 exploration line in the upper east section of the ore body. The average grade of ore is TFe35.64\% and $\mathrm{mFe} 26.78 \%$.

Ore bodies I-19 (formerly II-2) are distributed between lines 4-8, only controlled by surface trenching engineering. The exposure elevation is $4560 \mathrm{~m}-4580 \mathrm{~m}$, and the strike length of the ore body is $79 \mathrm{~m}$. It is estimated that the depth of the slope is $20 \mathrm{~m}$ and the thickness of the ore body is $6.79 \mathrm{~m}$. The ore body is lens-like, and its occurrence is $295^{\circ} \sim 315^{\circ} \angle 28^{\circ} \sim 37^{\circ}$. The wall rock of the ore body is dominated by tremolite (actinolite) skarn. The ore is dominated by magnetite, followed by pyrite magnetite ore. The average grade of ore is $\mathrm{TFe} 46.40 \%$ and $\mathrm{mFe} 42.67 \%$.

\subsection{Features of Wall Rock and Intercalated Rocks}

\subsubsection{Types of Wall Rocks of the Ore Body}

The wall rocks of the ore body are mainly diopside tremolite skarn, diopside garnet skarn, diopside epidote chlorite skarn, silicified marble and potash granite gneiss.

The wall rocks near the mine are mainly skarn, followed by silicified marble, mixed petrified gneiss, etc., with medium hardness and relative stability. However, the mixed petrified gneiss is mainly composed of schistosity, and is brittle and relatively broken, which is not good for mining. 
The occurrence of the ore body is basically the same as that of the wall rock, and the boundary between the ore body and the wall rock is not clear, showing a gradual relationship.

\subsubsection{Orebody Interlayer and Characteristics}

The ore bodies are mostly distributed in the shape of parallel veins and parallel complex veins. The interlayers of the ore bodies are widely distributed, and the composition of them is basically the same as that of the wall rocks. They are all skarns with a thickness of 1-6 meters. Generally, the grade increases when it is close to the ore body, and the TFe is generally between 5-10\%, while the content of other elements is very low. Due to the small overall thickness of the ore body, there are a few interlayers in the ore body. The thickness is less than $1.0 \mathrm{~m}$, and the TFe is generally $10-15 \%$.

\section{Genesis of the Deposit}

According to the comprehensive analysis of the characteristics of the surrounding rocks of the ore body and the structural structure of the ore, the genesis of the deposit is very complicated, but the existing available data showed that it should belong to the skarn deposit related to mixed petrification. It basically has the following characteristics:

(1) The ore bodies are mainly produced in the mixed petrified gneiss strata of the Lower Proterozoic Lower Rock Group of the Jinshuikou Group of the Proterozoic. Rock mixed petrification is strong, and generally contains high iron, which is the main source of mineralization.

(2) The ore-bearing wall rocks of the deposit are mainly skarn. The skarn is lens-like and layer-like and distributed in parallel in the mixed petrified gneiss, which is basically consistent with the occurrence of gneiss. The outer zone where the skarn and gneiss in this deposit are in contact with potash-granite gneiss, and it is a product of mixed petrification.

(3) There are silicified marbles in the skarn contact zone and nearby, indicating that skarn is a metamorphic product of marble. According to predecessors' temperature measurement for inclusions of ore minerals and gangue minerals in the mining area, the formation temperature of magnetite is between $500^{\circ} \mathrm{C}$ and $200^{\circ} \mathrm{C}$, and thus this deposit belongs to high-medium temperature hydrothermal metamorphic deposit.

(4) The magmatic rocks in the mining area are mainly granite and diorite formed in the variscan period, distributed on the north and south sides of the ore belt. They provide a heat source and ore-forming materials for the later transformation of the deposit, further enrich the magnetite to form ore-rich bodies, and enrich copper and Zn ore-forming materials to form copper and zinc ore bodies. Among them, the copper and zinc ore bodies are generally distributed in the deep or edge, that is, the section closer to the magmatic rock.

(5) The shape of the ore body is complicated, mainly lens-like and vein-like, followed by lentil-like, pod-like and irregular-shaped ores. There is obvious boundary between the ore body and the surrounding rocks. Ore structures include massive structure, disseminated structure, strip structure and veinlet structure, with obvious hydrothermal metasomatic-filling characteristics.

\section{Conclusion}

The Qunli Iron Mine is a skarn-type iron deposit related to the migmatization of medium and small scales, and the mineralization and magmatism are closely related. At present, $5 \mathrm{Fe}(\mathrm{Cu})$ ore (body) groups have been circled in the mining area, and $42 \mathrm{Fe}$ ore bodies and $5 \mathrm{Cu}$ ore bodies have been delineated. However, the degree of ore body engineering control is uneven due to the limitation of detailed investigation work in this mining area. At present, only the section above the 4100m elevation between the 1-17 exploration line of Orebody Group I has systematic engineering control, which has reached the level of general exploration. The degree of engineering control in the remaining sections is still poor, and the degree of research is also low. Especially in the Middle East section and the north and south sides of the mining area, the degree of engineering control is poor, with only a small amount of trenching and drilling engineering control understanding on the surface or shallow parts. The strike and tendency of the ore body are not fully controlled, and the scale of 
the ore body is unclear. Most of the 1/10,000 high-precision magnetic survey anomalies delineated in the mining area have not been verified or fully inspected. Therefore, it is believed that this area still has a large prospecting space and prospects, and it is expected to form a medium and large iron polymetallic deposit.

\section{References}

[1] Li Jun, Lu Linxiang, et al. Geological Characteristics and Prospecting Prospect of Wulasitaigoukou Gold Deposit in Dulan County of Qinghai Province [J]. Shandong Land and Resources, 2016 (09): 1-5+9

[2] Ge Yuejin, Lu Qing, Shi Guoping. Study on Geological Characteristics and Genesis of Early Triassic Intermediate-acid Intrusive Rocks in the North of Watershed in Middle and West Section of East Kunlun [J]. Shandong Land and Resources, 2018 (08): 6-12

[3] Hou Zheng, Hou Hui, et al. Analysis of Geological Characteristics and Ore-controlling Factors of Hongshigou Polymetallic Deposit in Qinghai [J]. Resources, 2018 (02): 36-37+51

[4] Yuan Mingkao. Typomorphic Characteristics and Gold-bearing Analysis of Pyrite in Xinchen Gold Deposit in Shandong Province [J]. Shandong Land and Resources, 2017 (06): 12-17

[5] Guan Xiangbo, Li Jun. Geological Characteristics and Prospecting Marks of Balong Rock Gold Deposit in Dulan County of Qinghai Province [J]. Shandong Land and Resources, 2016 (12): 14-18 